\title{
Surface Roughness of Thermally Treated Wood Cut with Different Parameters in CNC Router Machine
}

\author{
Hüseyin Pelit,* Mustafa Korkmaz, and Mehmet Budakçı \\ The effects of different machining parameters on surface roughness \\ values of thermally treated pine, beech, and linden woods cut in a \\ computer numerical control (CNC) router machine were examined. Wood \\ specimens were thermally treated at 170,190 , and $210^{\circ} \mathrm{C}$ for $2 \mathrm{~h}$. Then, \\ specimens were cut in the radial and tangential directions with three \\ different spindle speeds $(12000,15000$, and $18000 \mathrm{rpm})$ and three \\ different feed rates $(3000,4000$, and $6000 \mathrm{~mm} / \mathrm{min}$ ) using two different \\ end mill tools (spiral and straight) on the CNC machine. The end mill type \\ significantly affected the roughness values of the untreated and thermally \\ treated specimens in both directions. Lower roughness values were found \\ in the specimens (especially pine) machined with the straight end mill \\ compared to those machined with the spiral end mill. Roughness generally \\ decreased in the thermally treated specimens. However, thermal \\ treatment temperature did not have a notable effect on roughness. As the \\ spindle speed increased, the roughness values of all specimens \\ decreased. In contrast, as the feed rate increased, the roughness values \\ increased. Therefore, the end mill type, feed rate, and spindle speed were \\ the most influential parameters on the roughness.
}

Keywords: CNC cutting; Processing parameter; Roughness; Thermal treatment; Wood material

Contact information: Department of Wood Products Industrial Engineering, Faculty of Forestry, Duzce University; 81620,Duzce, Turkey; *Corresponding author: huseyinpelit@duzce.edu.tr

\section{INTRODUCTION}

Wood is widely used in interior and exterior decoration due to its ease of processing, low energy consumption during processing, availability in different colors and patterns, sound and heat insulation properties, and suitability for surface treatments (Ross 2010). Raw wood material becomes a final product after processes such as cutting, planing, and sanding (Sofuoğlu and Kurtoğlu 2015).

Wood modification improves the properties of wood to provide a longer service life compared with the unmodified standard product (Hill 2006). Thermal treatment, which is one of the oldest known environmentally friendly modification methods, causes changes in the chemical composition of the wood material, making it more resistant to water, microorganisms, and some insects. In addition, it reduces the equilibrium moisture content, the wettability, and the thermal conductivity of wood (Kamdem et al. 2002; Tjeerdsma and Militz 2005; Yang et al. 2007; Kocaefe et al. 2008; Esteves and Pereira 2009; Kaygin et al. 2009; Tumen et al. 2010). Consequently, wood modification by thermal treatment is increasingly being used to improve the properties of wood species that are not suitable for outdoor applications or for use in wet spaces (Hill 2006; Boonstra 2016). However, when thermal treatment is applied, the density and mechanical resistance of the wood decrease due to thermal degradation and mass loss. The amount of reduction in these properties depends on parameters such as the thermal treatment method, application time, 
temperature, and the anatomical structure of the wood (Boonstra et al. 2007; Korkut et al. 2008; Cui et al. 2017; Pelit et al. 2018).

Computer numerical control (CNC) machines are increasingly used in the woodworking industry as well as in all industries focused on materials processing. These machines are a desirable alternative to traditional machines because they can perform operations such as drilling and cutting with high precision and speed, work in harmony with automated systems, and reduce the required time, cost, and labor. The purchasing cost of CNC machines, which has been a problem for small- and medium-sized enterprises up to now, is gradually decreasing due to competition and developing technology in CNC production, and these machines are becoming affordable and accessible for companies.

Wood milling, which is currently at the center of the furniture manufacturing industry, is the name given to the process of removing chips of various sizes and shapes from the wood surface (Sedlecký et al. 2018). During chip removal, the cutter tool rotates around its axis and the individual teeth gradually enter through the workpiece, which moves simultaneously against the movement of the tool (Prokeš 1982). The blades of the milling cutter gradually remove chips from the machined material (Kvasnová et al. 2017; Klopanová et al. 2017). Processing wood materials with different anatomical structures by using different parameters on these machines, where the spindle speed and feed rate can be precisely adjusted compared to conventional machines, yields different results on the cut surfaces.

Surface roughness, an important criterion in determining the qualities of final products, is a product of processing conditions and the anatomical structure of the wood (Csanády and Magoss 2013). The most important factors related to processing conditions are cutting speed, tooth pitch, blade sharpness, cutting angle, and cutting direction; and factors related to wood properties are density, moisture content, and anatomical properties (Williams et al. 1996; Davim 2011). Therefore, it is important to evaluate the processing conditions and factors related to wood properties to achieve a high-quality surface. High surface roughness values that may arise due to the application of incorrect processing parameters have direct negative effects on the adhesion and other surface treatments to be applied. Extra post-processing operations such as scraping and sanding to eliminate such negativities cost time and money for companies.

In the past, the quality of the machined surface was measured in most cases by visual and tactile controls (Sedlecký et al. 2018). Although these methods are economical and fast, they are subjective and depend on the perceptions of the operator. Thanks to developments in measurement technology, it has become possible to measure the surface roughness of materials numerically (Hızıroğlu 1996). It is important to study the effects of different parameters on the surface roughness to obtain smoother surfaces, and it is clear that more studies are needed. This study aimed to determine the effects of machining parameters on the surface quality of thermally treated wood samples.

\section{EXPERIMENTAL}

\section{Materials}

Scotch pine (Pinus sylvestris L.), eastern beech (Fagus orientalis Lipsky), and linden (Tilia grandifolia Ehrh.) woods were studied because they are widely used in the woodworking and furniture industries, and they have various applications, such as in decorations and wooden toys. Woods with a moisture content of approximately $11 \%$ to 
$14 \%$ were selected randomly from a timber company in Düzce, Turkey. Attention was paid to ensure that no rot, knots, cracks, or density differences were present in the specimens. The specimens were cut in two groups (radial and tangential directions) in draft dimensions of $70 \mathrm{~mm} \times 50 \mathrm{~mm} \times 600 \mathrm{~mm}$ (tangential $(\mathrm{T}) \times$ radial $(\mathrm{R}) \times$ longitudinal $(\mathrm{L}))$ and $50 \mathrm{~mm}$ $\times 70 \mathrm{~mm} \times 600 \mathrm{~mm}(\mathrm{~T} \times \mathrm{R} \times \mathrm{L})(\mathrm{TS} 2470$ 1976). Before thermal treatment, the specimens were held in a conditioning cabin (relative humidity (RH) $65 \% \pm 3 \%$ and $20{ }^{\circ} \mathrm{C} \pm 2{ }^{\circ} \mathrm{C}$ ) until they reached a stable weight. The air-dry density values of the wood specimens were measured as $536 \mathrm{~kg} / \mathrm{m}^{3}$ for pine, $691 \mathrm{~kg} / \mathrm{m}^{3}$ for beech, and $495 \mathrm{~kg} / \mathrm{m}^{3}$ for linden (TS 2472 1976).

\section{Thermal treatment}

The thermal treatment was performed in a specially designed laboratory-type thermal treatment oven (Orent Forest Products, Machinery, Trade, and Ind. Inc., Düzce, Turkey) with automatic control and integrated steam generator (Fig. 1).
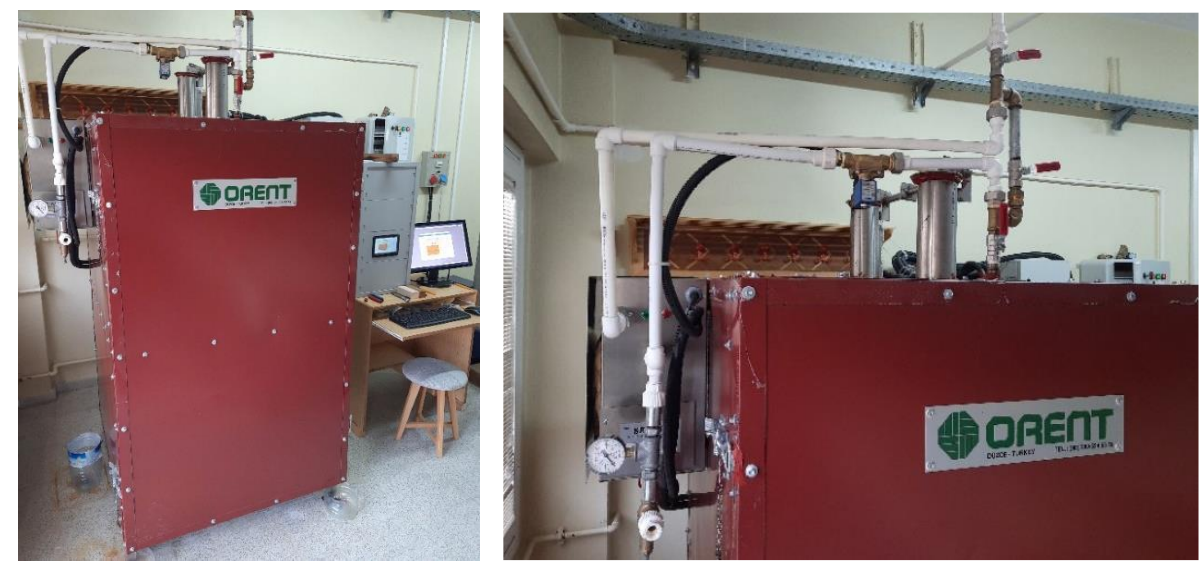

Fig. 1. Thermal treatment furnace and equipment

Thermal treatment was performed in three stages ((1) drying at elevated temperature, (2) thermal treatment, and (3) cooling and conditioning) and under the protection of water vapor according to the methods described in the ThermoWood Handbook (Finnish ThermoWood Association 2003). In the first stage, specimens were dried to approximately $0 \%$ moisture by increasing the furnace temperature with heat and steam. In the second stage, heat, at three different target temperatures $\left(170{ }^{\circ} \mathrm{C}, 190{ }^{\circ} \mathrm{C}\right.$, and $210{ }^{\circ} \mathrm{C}$ ), was applied to the specimens for $2 \mathrm{~h}$. In the third stage (conditioning), the temperature was reduced, and the moisture ratio of the specimens was brought to $4 \%$ to $6 \%$ by applying water spray.

After the thermal treatment, the specimens remained in a conditioning cabin (RH $65 \% \pm 3 \%$ and $20{ }^{\circ} \mathrm{C} \pm 2{ }^{\circ} \mathrm{C}$ ) for four weeks. Then, specimens were cut in two groups in final dimensions of $60 \mathrm{~mm} \times 40 \mathrm{~mm} \times 550 \mathrm{~mm}(\mathrm{~T} \times \mathrm{R} \times \mathrm{L})$ and $40 \mathrm{~mm} \times 60 \mathrm{~mm} \times 550$ $\mathrm{mm}(\mathrm{T} \times \mathrm{R} \times \mathrm{L})$. Twenty-four test specimens were prepared for each of the three wood species (72 in total).

\section{Cutting of wood specimens in CNC router machine}

A 3-axis CNC milling machine (TCM35, Tuğcu Machinery, İstanbul, Turkey) was used to cut the thermally treated and untreated (control) wood specimens with different parameters. The parameters used in the cutting process are shown in Table 1. 
To prevent movement and vibration during the cutting process, the specimens were fixed to the machine table. The cutting of the wood specimens was performed by the pocket machining method by moving the end mill tool perpendicular to the wood fibers in both the radial and tangential directions (Fig. 2).

Table 1. Machining Parameters in CNC Milling

\begin{tabular}{|c|c|}
\hline Cutting Direction & Tangential, radial \\
\hline End Mill Type & Straight end mill, spiral end mill \\
\hline Spindle Speed $(\mathrm{rpm})$ & $12000,15000,18000$ \\
\hline Feed Rate $(\mathrm{mm} / \mathrm{min})$ & $3000,4000,6000$ \\
\hline Cutting (Chip) Depth $(\mathrm{mm})$ & 4 \\
\hline Tool Diameter $(\mathrm{mm})$ & 10 \\
\hline
\end{tabular}
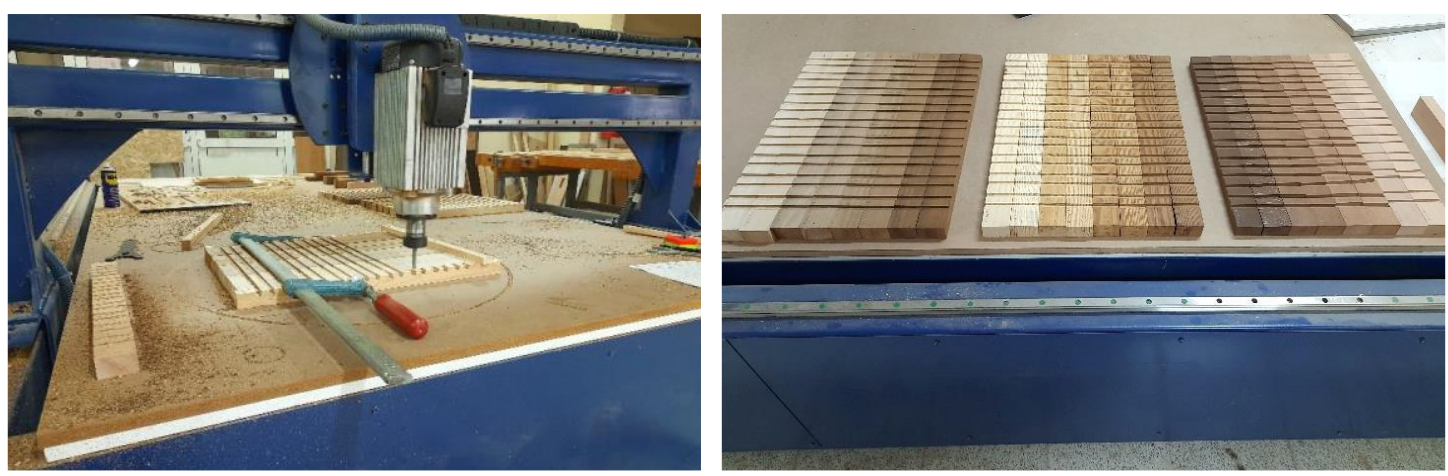

Fig. 2. Cutting specimens with $\mathrm{CNC}$ router machine

The cutting process was performed using a new end mill tool for each wood group. The dimensions of the spiral and straight end mill tools used in the study are shown in Fig. 3.

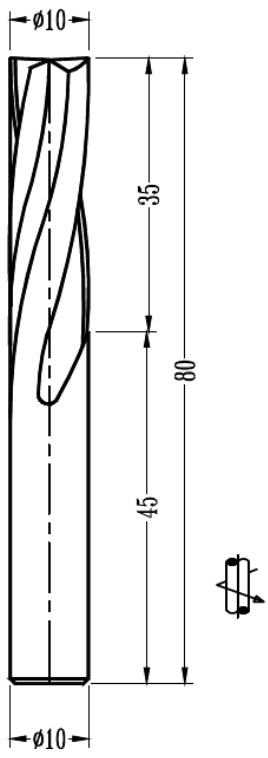

(a)

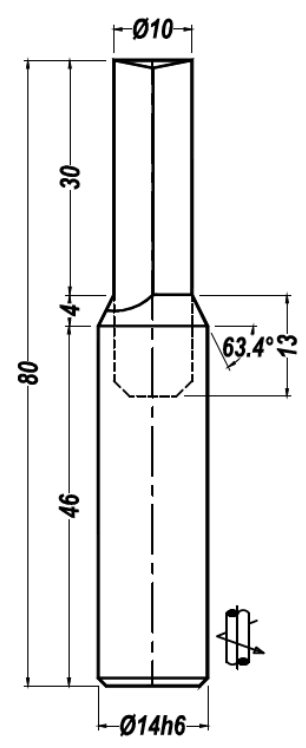

(b)

Fig. 3. End mill tools used in the cutting process: (a) spiral end mill and (b) straight end mill (dimensions are in $\mathrm{mm}$ ) 


\section{Methods}

Determination of surface roughness

Roughness values of the wood specimens were determined using a Time TR200 (Time Group Inc., Beijing, China) surface roughness tester. The parameters $R_{\mathrm{a}}, R_{\mathrm{y}}$, and $R_{\mathrm{z}}$ are generally used in the numerical expression of wood surface roughness. The $R_{\mathrm{a}}$ parameter was measured to evaluate the surface roughness values of the specimens according to ISO 4287 (1997). The $R_{\text {a }}$ parameter is the arithmetic mean of the absolute values of the profile departures.

After setting the roughness measuring device to a measuring speed of $15 \mathrm{~mm} / \mathrm{min}$, a measuring step length of $2.5 \mathrm{~mm}$, and a measurement number of 5, six measurements ( $n$ $=6)$ were taken from two different points of the three channels cut for each selected processing parameter. Measurements were made in the direction perpendicular to the fibers (cutting direction) (Fig. 4). Approximately 864 measurements ( 2 cutting directions $\times 2$ end mill types $\times 4$ thermal treatment temperatures $\times 3$ spindle speeds $\times 3$ feed rates $\times 6$ measurement repetitions) were made for each wood species, and a total of 2592 measurements (864 measurements $\times 3$ wood species) were taken.
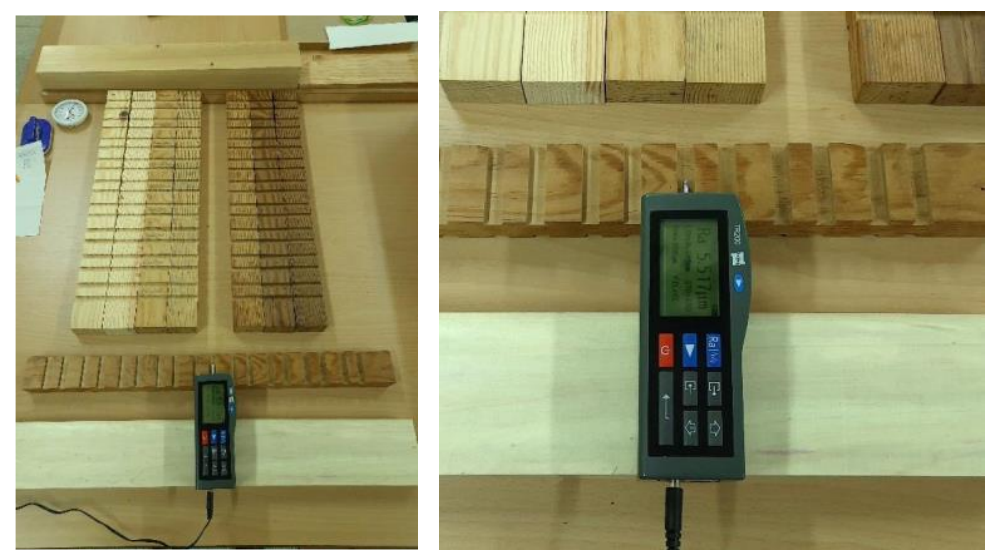

Fig. 4. Roughness measurement in wood specimens

\section{Statistical analysis}

The MSTAT-C 2.1 software (Michigan State University, East Lansing, MI, USA) was used for statistical analysis. Analysis of variance (ANOVA) tests were performed to determine the effects of the selected machining parameters in CNC cutting on the surface roughness values of the thermally treated wood specimens at the 0.05 significance level. Significant differences between the variables were compared using Duncan's test.

\section{RESULTS AND DISCUSSION}

The ANOVA results of the surface roughness values of the specimens machined with the $\mathrm{CNC}$ router machine using different cutting parameters and end mill tool types are shown in Table 2. The results showed that cutting direction, end mill tool type, thermal treatment temperature, spindle speed, and feed rate had statistically significant effects on the surface roughness values for all wood species $(p \leq 0.05)$. However, the interaction of these factors did not have a significant effect on the surface roughness. 
Table 2. ANOVA Results for Roughness Values of Wood Specimens

\begin{tabular}{|c|c|c|c|c|c|c|}
\hline \multirow{2}{*}{ Source } & \multicolumn{2}{|c|}{ Pine } & \multicolumn{2}{c|}{ Beech } & \multicolumn{2}{c|}{ Linden } \\
\cline { 2 - 7 } & F-ratio & p-value & F-ratio & p-value & F-ratio & p-value \\
\hline $\begin{array}{c}\text { Cutting } \\
\text { direction and } \\
\text { tool type (A) }\end{array}$ & 438.3123 & $0.0000^{*}$ & 108.1787 & $0.0000^{*}$ & 28.2182 & $0.0000^{*}$ \\
\hline $\begin{array}{c}\text { Thermal } \\
\text { treatment } \\
\text { temperature } \\
\text { (B) }\end{array}$ & 6.5881 & $0.0002^{*}$ & 2.4629 & $0.0414^{*}$ & 5.1172 & $0.0017^{*}$ \\
\hline $\begin{array}{c}\text { Spindle speed } \\
(\mathrm{C})\end{array}$ & 95.8016 & $0.0000^{*}$ & 111.1121 & $0.0000^{*}$ & 56.0706 & $0.0000^{*}$ \\
\hline Feed rate (D) & 177.6380 & $0.0000^{*}$ & 179.2757 & $0.0000^{*}$ & 208.9119 & $0.0000^{*}$ \\
\hline $\begin{array}{c}\text { Interaction } \\
\text { (ABCD) }\end{array}$ & 0.2571 & $\mathrm{NS}$ & 0.5888 & $\mathrm{NS}$ & 0.3844 & $\mathrm{NS}$ \\
\hline
\end{tabular}

${ }^{*}$ Significant at 95\% confidence level; NS: not significant

Results of Duncan's one-way test conducted for comparisons of the means of surface roughness values in thermally treated wood specimens cut with different processing parameters in the $\mathrm{CNC}$ router machine are shown in Table 3. In terms of cutting direction (also roughness measuring direction), the surface roughness value was higher for the radially cut surfaces in pine specimens and for the tangentially cut surfaces in beech and linden specimens. Arguably, this is due to the differences between the surface texture structures and natural anatomical features of the wood species. In general, the surface quality of machined wood is affected by many factors related to the processing conditions and wood properties. The most important factors related to the properties of the wood are the density, moisture content, and anatomical structure. The degree of surface roughness of the wood is directly related to the combination of the processing conditions and the anatomical structure of the wood (Sieminski and Skarzynska 1987; Aydın and Çolakoğlu 2003; Tiryaki 2014; Csanády et al. 2015). Regarding the end mill tool type, surface roughness values were higher in all specimens machined with the spiral end mill tool (Figs. 5 to 7). In other words, smoother surfaces were obtained in wood specimens machined with the straight end mill tool. Roughness values increased by $39 \%, 17 \%$, and $8 \%$, respectively, in pine, beech, and linden specimens machined with the spiral end mill compared to those machined with the straight end mill. It has been observed that the choice of end mill is important for obtaining smooth surfaces in pocket machining applications, especially in pine wood specimens. The end mill geometry influences the results. The straight end mill geometry is different than the spiral end mill geometry. While the cutting edge of the straight end mill is in a straight line like a plane iron, the cutting edge of the spiral end mill has a circular shape. In addition, the cutting edge of the straight end mill removes a larger area compared to the cutting edge of the spiral end mill. This situation may also have had an impact on the results. As a result of cutting the cell formations during wood processing, grooves are formed between tracheae, tracheids, medullary rays, parenchyma cells, resin channels, and fibers. The dimensions of these grooves vary depending on the wood type, the proportion of earlywood or latewood and the cutting direction. These are also the main factors in the surface roughness of the wood (Stumbo 1963; Peters and Cumming 1970; Sögütlü 2005). In addition, it is possible to obtain smoother surfaces by selecting the appropriate end mill geometry for processing wood (Tiryaki 2014).

Thermal treatment affected the surface roughness values of each wood species 
differently. However, the differences between the roughness values of the thermally treated pine specimens (at $170{ }^{\circ} \mathrm{C}, 190{ }^{\circ} \mathrm{C}$, and $210{ }^{\circ} \mathrm{C}$ ) were statistically insignificant (Table 3). Roughness values generally decreased after thermal treatment in pine specimens cut in both directions. In addition, as the thermal treatment temperature increased, the roughness tended to increase in pine specimens cut in the radial direction. However, temperature increase did not have a significant effect on pine specimens cut in the tangential direction (Fig. 5). For beech wood, the highest roughness value $(6.63 \mu \mathrm{m})$ was found in untreated specimens, and the lowest roughness value $(6.47 \mu \mathrm{m})$ was found in the specimens thermally treated at $170{ }^{\circ} \mathrm{C}$. However, no statistically significant difference was observed between the roughness values of the untreated specimens and the specimens thermally treated at 190 and $210{ }^{\circ} \mathrm{C}$ (Table 3). The roughness values of the beech specimens cut in the radial direction decreased slightly after thermal treatment, but the effect of temperature increase was not obvious. While the roughness value decreased slightly in the tangential specimens thermally treated at low temperature $\left(170{ }^{\circ} \mathrm{C}\right)$, it tended to increase in specimens treated at higher temperatures $\left(190\right.$ and $\left.210^{\circ} \mathrm{C}\right)$ (Fig. 6).

Table 3. Duncan's Test Results for Means of Roughness Values

\begin{tabular}{|c|c|c|c|c|c|c|}
\hline \multirow[b]{2}{*}{ Factor } & \multicolumn{2}{|c|}{ Pine } & \multicolumn{2}{|c|}{ Beech } & \multicolumn{2}{|c|}{ Linden } \\
\hline & $\begin{array}{c}\text { Mean } \\
(\mu \mathrm{m})\end{array}$ & SG & $\begin{array}{c}\text { Mean } \\
(\mu \mathrm{m})\end{array}$ & SG & $\begin{array}{c}\text { Mean } \\
(\mu \mathrm{m})\end{array}$ & SG \\
\hline \multicolumn{7}{|c|}{ Cutting Direction and End Mill Type } \\
\hline $\mathrm{R}$ - straight end mill & 5.07 & $\mathrm{c}$ & 6.04 & $\mathrm{~d}$ & 6.96 & $\mathrm{c}$ \\
\hline$R$ - spiral end mill & 6.71 & $a$ & 6.94 & $b$ & 7.19 & $\mathrm{~b}$ \\
\hline $\mathrm{T}$ - straight end mill & 4.83 & d & 6.27 & c & 6.81 & $\mathrm{~d}$ \\
\hline T - spiral end mill & 6.57 & $\mathrm{~b}$ & 7.08 & $\mathrm{a}$ & 7.35 & $\mathrm{a}$ \\
\hline \multicolumn{7}{|c|}{ Thermal Treatment Temperature $\left({ }^{\circ} \mathrm{C}\right)$} \\
\hline Untreated & 5.95 & $\mathrm{a}$ & 6.63 & a & 6.94 & $\mathrm{C}$ \\
\hline 170 & 5.68 & $\mathrm{~b}$ & 6.47 & $b$ & 7.05 & $\mathrm{bc}$ \\
\hline 190 & 5.72 & $\mathrm{~b}$ & 6.62 & $a$ & 7.18 & $\mathrm{a}$ \\
\hline 210 & 5.81 & $\mathrm{~b}$ & 6.61 & $\mathrm{a}$ & 7.13 & $a b$ \\
\hline \multicolumn{7}{|c|}{ Spindle Speed (rpm) } \\
\hline 12000 & 6.14 & $a$ & 7.02 & $a$ & 7.38 & $\mathrm{a}$ \\
\hline 15000 & 5.87 & $\mathrm{~b}$ & 6.60 & $b$ & 7.04 & $\mathrm{~b}$ \\
\hline 18000 & 5.36 & $\mathrm{C}$ & 6.14 & $\mathrm{c}$ & 6.80 & $\mathrm{C}$ \\
\hline \multicolumn{7}{|c|}{ Feed Rate $(\mathrm{mm} / \mathrm{min})$} \\
\hline 3000 & 5.27 & C & 6.07 & C & 6.55 & c \\
\hline 4000 & 5.76 & $\mathrm{~b}$ & 6.49 & $b$ & 7.00 & $\mathrm{~b}$ \\
\hline 6000 & 6.35 & $\mathrm{a}$ & 7.18 & $\mathrm{a}$ & 7.67 & $\mathrm{a}$ \\
\hline
\end{tabular}

SG: statistical group (different letters denote significant differences); R: radial; T: tangential

For linden wood, the highest roughness value $(7.18 \mu \mathrm{m})$ was found in the specimens thermally treated at $190{ }^{\circ} \mathrm{C}$, and the lowest roughness value $(6.94 \mu \mathrm{m})$ was found in the untreated specimens. The roughness values of the linden specimens cut in the radial direction increased depending on the thermal treatment temperature. The roughness value of the radial linden specimens thermally treated at $210{ }^{\circ} \mathrm{C}$ increased by $6.2 \%$ compared to the untreated specimens. No significant change was observed in the roughness values of the thermally treated specimens cut in the tangential direction (Fig. 7). It can be said that this difference between radial and tangential surfaces is caused by micro cracks on wooden surfaces as a result of thermal processing. 

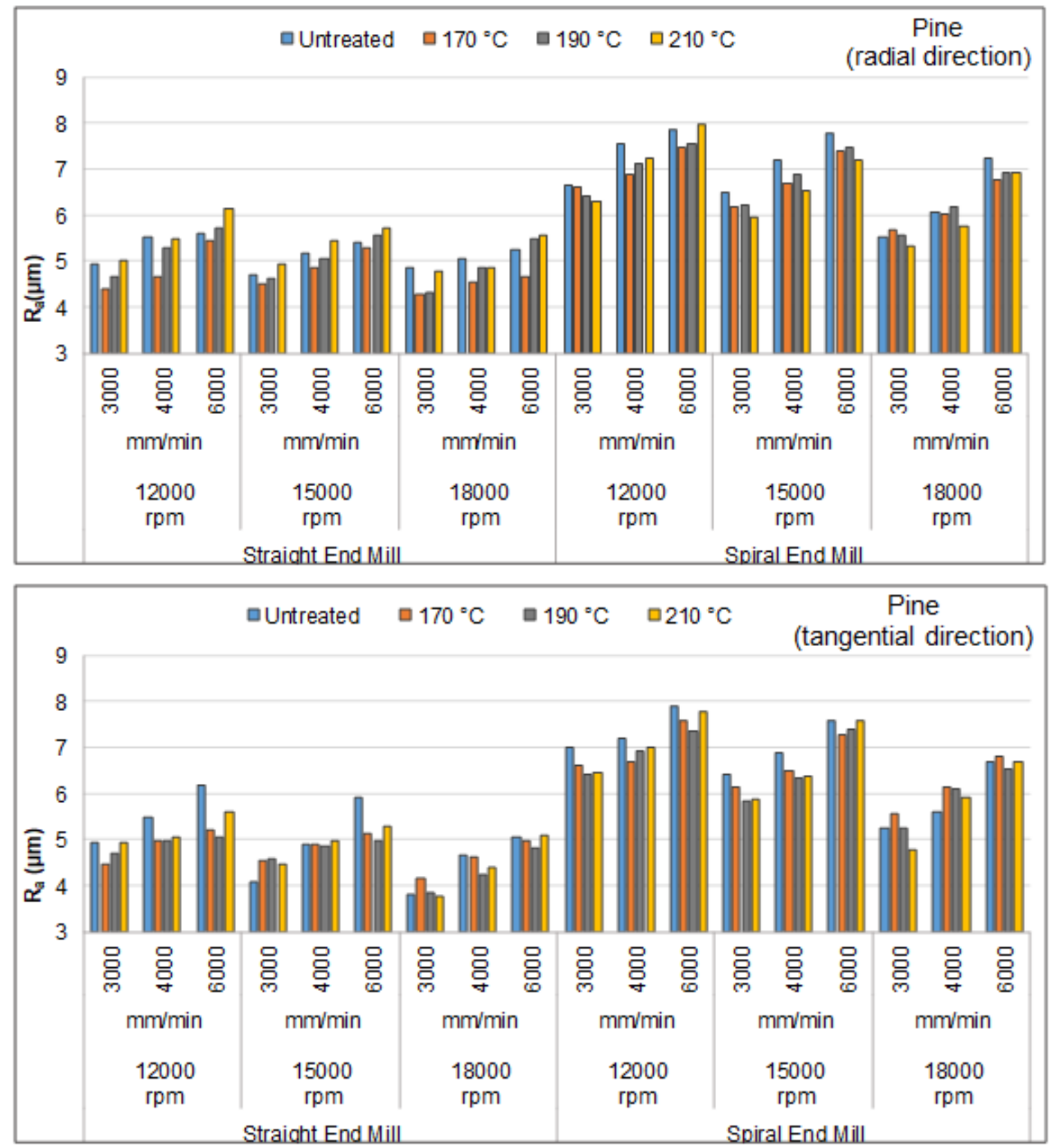

Fig. 5. Roughness values of thermally treated pine wood samples cut with different parameters

Thermal degradation in the chemical components of wood increases with the increase in heat treatment temperature, and this affects the surface roughness. This situation may have negatively affected the roughness value of the radial surface, which has a rougher structure than the tangential surface even in the untreated control samples (Jankowska 2020). In a previous study, the surface roughness values of pine, beech, fir, and poplar woods that were thermally treated at different temperatures and durations and machined in a $\mathrm{CNC}$ router machine were determined, and it was reported that the surface roughness decreased with increasing thermal treatment temperature. On the other hand, it was stated that the effect of heat treatment on the surface roughness was statistically insignificant for the wood type and cutting direction (Karagöz et al. 2011). Investigating previous studies 
on the surface roughness properties of thermally treated woods, it is observed that sanding increases the surface roughness values of pine and beech woods depending on the increase in thermal treatment temperature (Pelit et al. 2015). The surface roughness values of thermally treated woods cut with circular saws with different tooth numbers are increased compared to untreated woods (Budakçı et al. 2011). In contrast, it has also been reported that the surface roughness values of thermally treated woods machined with star and razor type blades in a horizontal milling machine decreased compared to untreated specimens (Budakçı et al. 2013).
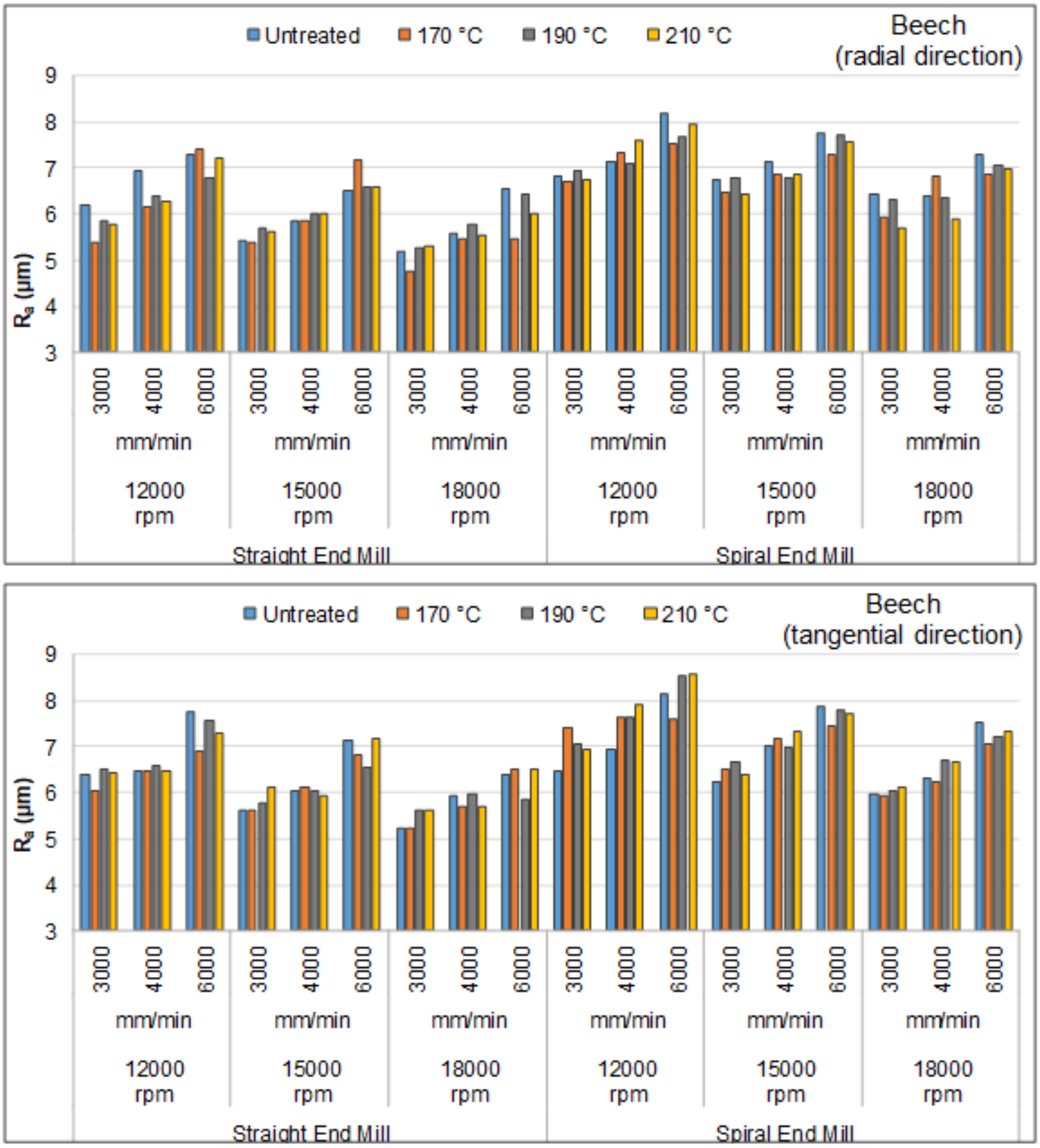

Fig. 6. Roughness values of thermally treated beech wood samples cut with different parameters 
In terms of spindle speed in the CNC router machine, in all wood species the highest roughness averages were obtained with the spindle speed of $12000 \mathrm{rpm}$, and the lowest values were obtained with the spindle speed of $18000 \mathrm{rpm}$ (Table 3). The roughness values of the specimens machined in both the radial and tangential directions decreased (and the surface smoothness improved) with increasing spindle speed (Figs. 5 to 7).
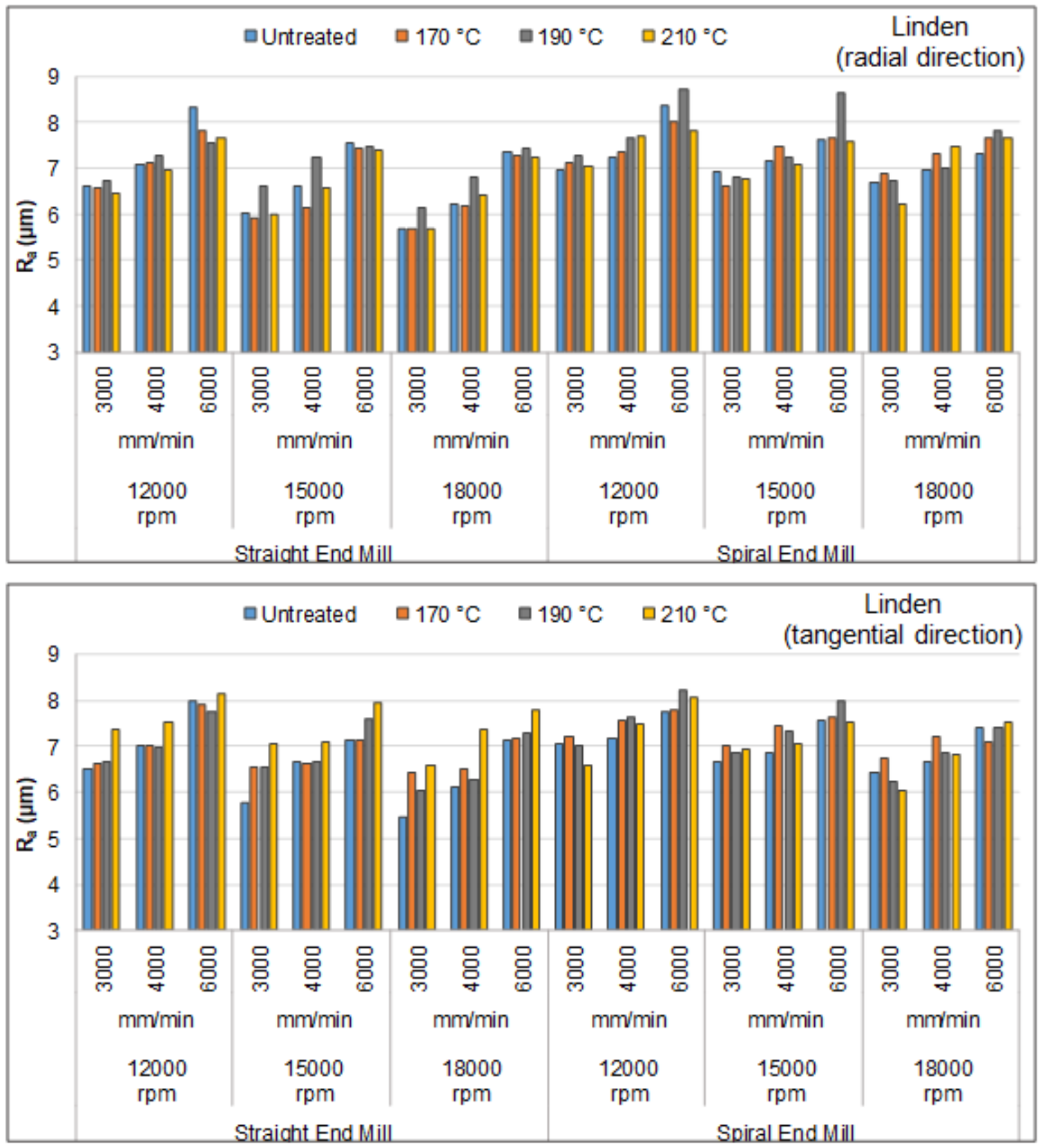

Fig. 7. Roughness values of thermally treated linden wood samples cut with different parameters

The roughness values of the pine, beech, and linden specimens machined in the radial direction at a spindle speed of $18000 \mathrm{rpm}$ decreased by $11 \%, 12 \%$, and $8 \%$, respectively, compared to those machined at a spindle speed of $12000 \mathrm{rpm}$. The roughness values of the specimens cut in the tangential direction decreased by $15 \%, 13 \%$, and $8 \%$, 
respectively. Arguably, the reason for the decreases in the surface roughness values with increasing spindle speed is that the contact between the cutting edge of the tool and the cut surface increases per unit time. It has been reported that high spindle speed and low feed rate decrease the surface roughness of wood in pocket machining with a CNC router machine, and therefore the spindle speed and feed rate considerably affect the surface quality (Davim et al. 2009; Karagöz 2011). In previous studies in which surface roughness was determined after processing different materials (wood, wood-based, or composite) with a CNC router machine, increases in the spindle speed reduced the roughness of the machined surface and increased the surface quality (Rawangwong et al. 2011; Aghakhani et al. 2013; Sütçü and Karagöz 2013; Patel and Patni 2014; Kaya et al. 2017).

Regarding feed rate in the CNC cutting, in all wood species the highest roughness values were obtained with the feed rate of $6000 \mathrm{~mm} / \mathrm{min}$, and the lowest roughness values were obtained with the feed rate of $3000 \mathrm{~mm} / \mathrm{min}$ (Table 3). The reason for the increase in the roughness values with increasing feed rate is that the contact time between the cutting edge of the mill and the cut surface decreases as the feed rate increases. Surface roughness values of wood specimens cut in the radial and tangential directions increased due to the increase in the feed rate (Figs. 5 to 7). The roughness values of the pine, beech, and linden specimens machined in the radial direction at a feed rate of $6000 \mathrm{~mm} / \mathrm{min}$ increased by $20 \%, 18 \%$, and $16 \%$, respectively, compared to those machined at a feed rate of 300 $\mathrm{mm} / \mathrm{min}$. Similarly, the tangential specimens' roughness values increased by $21 \%, 18 \%$, and $19 \%$, respectively. In a previous study, the feed rate was defined as the time the material was subjected to the cutting process, and it was stated that a decrease in the feed rate means that a point on the material is in contact with the end mill tool for a longer time (Pelit and Yaman 2020). It has also been reported in previous studies that the surface roughness values of wood or wood-based materials machined with a CNC router machine increase due to increasing feed rate, and the surface quality decreases (Mitchell and Lemaster 2002; Iskra and Tanaka 2005; Davim et al. 2009; Karagöz 2010; Rawangwong et al. 2011; Kaya et al. 2017).

\section{CONCLUSIONS}

1. The surface roughness properties of thermally treated yellow pine, beech, and lime wood specimens, which were cut with different processing parameters and different end mill tools on a CNC machine, were investigated. The end mill type significantly affected the surface roughness values of both the untreated and thermally treated wood materials. Lower roughness values were found in the specimens (especially in pine) machined with the straight end mill compared to those machined with the spiral end mill.

2. Surface roughness values generally tended to decrease in thermally treated wood specimens (except for linden) compared to untreated specimens. However, the thermal process temperature did not have a significant effect on the roughness values.

3. Surface roughness values of all wood specimens (both untreated and thermally treated) decreased with increasing spindle speed, and thus smoother surfaces were obtained. Compared to the specimens machined at a spindle speed of $12000 \mathrm{rpm}$, the roughness values of the specimens machined at a spindle speed of $18000 \mathrm{rpm}$ decreased by up to $15 \%$. 
4. As the feed rate increased, the roughness values increased, and the surface smoothness decreased in all specimens. Compared to the specimens cut at a feed rate of 3000 $\mathrm{mm} / \mathrm{min}$, the roughness values of the specimens cut at a feed rate of $6000 \mathrm{~mm} / \mathrm{min}$ increased by up to $21 \%$.

5. Therefore, while end mill type, feed rate, and spindle speed were of primary importance to the surface roughness values of thermally treated wood materials cut by pocket machining in a CNC router machine, thermal treatment temperature and cutting direction were less important.

\section{ACKNOWLEDGMENTS}

The authors are grateful for the support of the Research Fund of Duzce University, Grant No. BAP-2018.07.01.742.

\section{REFERENCES CITED}

Aghakhani, M., Khazaeian, A., and Madhoushi, M. (2013). "Different CNC machining condition of Paulownia wood by CNC; Influence on the Abbott roughness parameters," Iranian Journal of Wood and Paper Science Research 28(2), 291-312.

Aydın, İ., and Çolakoğlu, G. (2003). "Roughness on wood surfaces and roughness measurement methods," Artvin Çoruh Üniversitesi Orman Fakültesi Dergisi 4(1), 92-102.

Boonstra, M. (2016). "Dimensional stabilization of wood and wood composites," in: Lignocellulosic Fibers and Wood Handbook: Renewable Materials for Today's Environment, N. Belgacem and A. Pizzi (eds.), Scrivener Publishing, Salem, MA, USA, pp. 629-655. DOI: 10.1002/9781118773727.ch26

Boonstra, M. J., Van Acker, J., Tjeerdsma, B. F., and Kegel, E. V. (2007). "Strength properties of thermally modified softwoods and its relation to polymeric structural wood constituents," Annals of Forest Science 64(7), 679-690. DOI: 10.1051/forest:2007048

Budakçı, M., İlçe, A. C., Gürleyen, T., and Utar, M. (2013). "Determination of the surface roughness of heat-treated wood materials planed by the cutters of a horizontal milling machine," BioResources 8(3), 3189-3199. DOI: 10.15376/biores.8.3.31893199

Budakçı, M., İlçe, A. C., Korkut, D. S., and Gürleyen, T. (2011). "Evaluating the surface roughness of heat-treated wood cut with different circular saws," BioResources 6(4), 4247-4258.

Csanády, E., and Magoss, E. (2013). "Mechanics of the cutting process," in: Mechanics of Wood Machining, Springer, Heidelberg, Germany, pp. 1-30. DOI: 10.1007/978-3642-29955-1_1

Csanády, E., Magoss, E., and Tolvaj, L. (2015). Quality of Machined Wood Surfaces, Springer, Cham, Switzerland. DOI: 10.1007/978-3-319-22419-0

Cui, W., Zhang, N., Xu, M., and Cai, L. (2017). "Combined effects of ZnO particle deposition and heat treatment on dimensional stability and mechanical properties of poplar wood," Scientific Reports 7(1). DOI: 10.1038/s41598-017-10606-5

Davim, J. P. (ed.) (2011). Wood Machining, ISTE Ltd, London, UK. DOI: 
$10.1002 / 9781118602713$

Davim, J. P., Clemente, V. C., and Silva, S. (2009). "Surface roughness aspects in milling MDF (medium density fibreboard)," The International Journal of Advanced Manufacturing Technology 40(1-2), 49-55. DOI: 10.1007/s00170-007-1318-z

Esteves, B. M., and Pereira, H. M. (2009). "Wood modification by heat treatment: A review," BioResources 4(1), 370-404. DOI: 10.15376/biores.4.1.370-404

Finnish ThermoWood Association (2003). ThermoWood Handbook, Finnish Thermowood Association, Helsinki, Finland.

Hill, C. A. S. (2006). "Thermal modification of wood," in: Wood Modification: Chemical, Thermal and Other Processes, John Wiley \& Sons, Ltd, Chichester, UK, pp. 99-127. DOI: 10.1002/0470021748.ch5

Hizıroğlu, S. (1996). "Surface roughness analysis of wood composites: A stylus method," Forest Products Journal 46(7/8), 67-72.

Iskra, P., and Tanaka, C. (2005). "The influence of wood fiber direction, feed rate, and cutting width on sound intensity during routing," Holz als Roh-und Werkstoff 63(3), 167-172. DOI: 10.1007/s00107-004-0541-7

ISO 4287 (1997). “Geometrical product specifications (GPS) — Surface texture: Profile method - Terms, definitions and surface texture parameters," International Organization for Standardization, Geneva, Switzerland.

Jankowska, A. (2020). "Understanding of surface roughness of wood based on analysis its structure and density," Annals of WULS Forestry and Wood Technology 111(2020), 27-31. DOI: 10.5604/01.3001.0014.6421

Kamdem, D. P., Pizzi, A., and Jermannaud, A. (2002). "Durability of heat-treated wood," Holz als Roh- und Werkstoff 60(1), 1-6. DOI: 10.1007/s00107-001-0261-1

Karagöz, Ü. (2010). Investigation of Machining Parameters on the Surface Quality in CNC Routing Wood and Wood-based Materials, Master's Thesis, Süleyman Demirel University, Isparta, Turkey.

Karagöz, Ü. (2011). "The effecting factors on surface quality of wood and wood-based materials machined by CNC," Kastamonu Üniversitesi Orman Fakültesi Dergisi 11(1), 18-26.

Karagoz, U., Akyıldız, M. H., and Isleyen, O. (2011). "Effect of heat treatment on surface roughness of thermal wood machined by CNC," Pro Ligno 7(4), 50-58.

Kaya, M., Imirzi, H. O., and Sogutlu, C. (2017). "Effect of cutter types, spindle speed and feed rate on the surface quality in CNC milling," in: The XXVIII ${ }^{\text {th }}$ International Conference: Research for Furniture Industry, Poznań, Poland.

Klopanová, V., Novák, V., Kvasnová, P., and Novák, D. (2017). "Theoretical basis of fractographic methods and their application in fracture modelling for Cr-Ni steels," Manufacturing Technology 17(6), 869-876.

Kocaefe, D., Poncsak, S., and Boluk, Y. (2008). "Effect of thermal treatment on the chemical composition and mechanical properties of birch and aspen," BioResources 3(2), 517-537.

Korkut, S., Kök, M. S., Korkut, D. S., and Gürleyen, T. (2008). "The effects of heat treatment on technological properties in red-bud maple (Acer trautvetteri Medw.) wood," Bioresource Technology 99(6), 1538-1543. DOI:

10.1016/j.biortech.2007.04.021

Kvasnová, P., Novák, D., and Novák, V. (2017). "Laser welding of aluminium alloys," Manufacturing Technology 17(6), 892-898.

Mitchell, P. H., and Lemaster, R. L. (2002). "Investigation of machine parameters on the 
surface quality in routing soft maple," Forest Products Journal 52(6), 85-90.

Patel, D. H., and Patni, V. N. (2014). "An investigation effect of machining parameters on CNC router," International Journal of Engineering Development and Research 2, 1583-1587.

Pelit, H., Budakç1, M., Sönmez, A., and Burdurlu, E. (2015). "Surface roughness and brightness of Scots pine (Pinus sylvestris) applied with water-based varnish after densification and heat treatment," Journal of Wood Science 61(6), 586-594. DOI: 10.1007/s10086-015-1506-7

Pelit, H., Budakçı, M., and Sönmez, A. (2018). "Density and some mechanical properties of densified and heat post-treated Uludağ fir, linden and black poplar woods," European Journal of Wood and Wood Products 76(1), 79-87. DOI: 10.1007/s00107017-1182-y

Pelit, H., and Yaman, Ö. (2020). "Influence of processing parameters on the surface roughness of solid wood cut by abrasive water jet," BioResources 15(3), 6135-6148. DOI: 10.15376/biores.15.3.6135-6148

Peters, C. C., and Cumming, J. D. (1970). "Measuring wood surface smoothness: A review," Forest Products Journal 20(12), 40-43.

Prokeš, S. (1982). “Obrábění Dřeva a Nových Hmot ze Dřeva (Woodworking and New Materials from Wood)," SNTL - Nakladatelství Technické Literatury, Prague, Czech Republic (in Czech).

Rawangwong, S., Chatthong, J., Rodjananugoon, J., and Boonchouytan, W. (2011). “A study of proper conditions in face milling palmyra palm wood by computer numerical controlled milling machine," Silpakorn University Science and Technology Journal 5(2), 33-39.

Ross, R. J. (2010). Wood Handbook: Wood as an Engineering Material (General Technical Report FPL-GTR-190), U. S. Department of Agriculture, Forest Service, Forest Products Laboratory, Madison, WI, USA. DOI: 10.2737/FPL-GTR-190

Sedlecký, M., Kvietková, M. S., and Kminiak, R. (2018). "Medium-density fiberboard (MDF) and edge-glued panels (EGP) after edge milling-surface roughness after machining with different parameters," BioResources 13(1), 2005-2021. DOI: 10.15376/biores.13.1.2005-2021

Sieminski, R., and Skarzynska, A. (1987). "Surface roughness of different species of wood after sanding," Przemysl Drzewny 38(9), 23-25.

Sofuoğlu, S. D., and Kurtoğlu, A. (2015). "Effects of machining conditions on surface roughness in planing and sanding of solid wood," Drvna Industrija 66(4), 265-272. DOI: $10.5552 /$ drind.2015.1406

Söğütlü, C. (2005). "The effect of some factors on surface roughness of sanded wood material," Journal of Polytechnic 8(4), 345-350. DOI: 10.2339/y2005.v8.n4.p345-350

Stumbo, D. A. (1963). "Surface texture measurement methods," Forest Products Journal 13(7), 299-304.

Sütçü, A., and Karagöz, Ü. (2013). "The influence of process parameters on the surface roughness in aesthetic machining of wooden edge-glued panels (EGPs)," BioResources 8(4), 5435-5448. DOI: 10.15376/biores.8.4.5435-5448

Tiryaki, S. (2014). "Effecting factors on surface roughness in wood machining," Turkish Journal of Forestry 15(2), 176-182.

Tjeerdsma, B. F., and Militz, H. (2005). "Chemical changes in hydrothermal treated wood: FTIR analysis of combined hydrothermal and dry heat-treated wood," Holz als Roh- und Werkstoff 63(2), 102-111. DOI: 10.1007/s00107-004-0532-8 
TS 2470 (1976). "Wood - Sampling methods and general requirements for physical and mechanical tests," Turkish Standards Institution, Ankara, Turkey.

TS 2472 (1976). "Wood - Determination of density for physical and mechanical tests," Turkish Standards Institution, Ankara, Turkey.

Tümen, I., Aydemir, D., Gündüz, G., Üner, B., and Çetin, H. (2010). "Changes in the chemical structure of thermally treated wood," BioResources 5(3), 1936-1944.

Williams, R. S., Knaebe, M. T., and Feist, W. C. (1996). Finishes for Exterior Wood: Selection, Application, and Maintenance, U. S. Department of Agriculture, Forest Service, Forest Products Laboratory, Madison, WI, USA.

Yang, H., Yan, R., Chen, H., Lee, D. H., and Zheng, C. (2007). "Characteristics of hemicellulose, cellulose and lignin pyrolysis," Fuel 86(12-13), 1781-1788. DOI: 10.1016/j.fuel.2006.12.013

Article submitted: March 26, 2021; Peer review completed: May 9, 2021; Revised version received and accepted: May 24, 2021; Published: May 28, 2021.

DOI: 10.15376/biores.16.3.5133-5147 